\title{
Anatomic-Imaging Correlations of Lumbar Disk-Vertebral Morphometric Indices
}

\author{
Correlaciones Anatomopatológicas de los Índices Morfométricos Disco-Vertebral Lumbar
}

\author{
D. M. Iliescu' ${ }^{1}$ P. Bordei ${ }^{1}$; E.V. Ionescu ${ }^{1,2}$; S. Albina ${ }^{3}$; C. Oprea ${ }^{2}$; B. Obada ${ }^{1,4}$; A. A. Lupu ${ }^{1,4}$; T.L. Hangan ${ }^{1}$ \& M.G. Iliescu ${ }^{1.3}$
}

\begin{abstract}
ILIESCU, D. M.; BORDEI, P.; IONESCU, E. V.; ALBINA, S.; OPREA, C.; OBADA, B.; LUPU, A. A.; HANGAN, T. L. \& ILIESCU, M. G. Anatomic-imaging correlations of lumbar disk-vertebral morphometric indices. Int. J. Morphol., 35(4):1553-1559, 2017.

SUMMARY: This study represents a morphometric assessment of the anterior segment of the lumbar spine, focused on the vertebral body - intervertebral disk assembly, calculating some specific indicators and then completing direct morphometry data with the data resulting from the imaging interpretation and subsequently correlating the same to map an anatomic-imaging model. The study was carried out with anatomic items from personal archive and images obtained from Computer Tomography (CT) and Magnetic Resonance Imaging (MRI) assessment. The morphometric assessment was carried out for intervertebral disks, the disk height in the anterior and posterior sections and correlated with the disk angle degree. Direct morphometric data was compared and correlated with the data resulting from the imaging interpretation. Direct morphometric assessment was carried out for 11 vertebral blocks; the vertebral blocks were sectioned and turned into 22 vertebral semi-blocks allowing easy access to absolutely all dimensional values pursued, including the ones covered by the posterior arc. The assessment of imaging data was made with CT, CT 3D and MRI investigations from the 120 subjects in the study. The disk sizes were assessed by direct measurements on the anatomic items and directly measured by means of the software for modern imaging examination. In case of significant differences between the vertebral bodies, the calculation of disk sizes was made indirectly, on grounds of the geometric interpretation of the vertebral body face sizes. The vertebral body / intervertebral disk (IVD) assembly represents a dynamic structure, permanently subject to changes and adaptation, IVD being capable of incurring changes for the entire life time, including growth changes; the growth, however, is not lineal, but a succession of thickening and getting thinner, in full concordance with the structural stresses and changes occurring inside.
\end{abstract}

KEY WORDS: Lumbar spine; Direct morphometry; Vertebral blocks.

\section{INTRODUCTION}

This study represents a morphometric assessment of the anterior segment of the lumbar spine, focused on the vertebral body - intervertebral disk assembly, calculating some specific indicators and then completing direct morphometry data with the data resulting from the imaging interpretation and subsequently correlating the same to map an anatomic-imaging model (Panjabi et al., 1992; van der Houwen et al., 2010).

\section{MATERIAL AND METHOD}

The study was carried out with anatomic items from personal archives and images obtained from CT and MRI imaging assessment. The morphometric assessment was carried out for intervertebral disks, the disk height in the anterior and posterior sections and correlated with the disk angle degree (Nissan \& Gilad, 1986; Aharinejad et al., 1990; Iliescu et al., 2006). The morphometric indices calculated were: the relative disk-vertebral index, respectively the disk height - intervertebral body height ratio and the disk-vertebral angle index (wedge index), respectively the angle between the vertebral body sides corresponding to the disk angle degree. Direct morphometric data was compared and correlated with the data resulting from the imaging interpretation. Direct morphometric assessment was carried out for 11 vertebral blocks; the vertebral blocks were sectioned and turned into 22 vertebral semi-blocks allowing the easy access to absolutely all dimensional values pursued, including the ones covered by the posterior arc (Fig. 1).

\footnotetext{
${ }^{1}$ Department of Anatomy, Faculty of Medicine, "Ovidius” University of Constanta, Constanta, Rumania.

${ }^{2}$ Balneal Recovery Sanatorium of Techirghiol, Techirghiol, Rumania.

${ }^{3}$ Rehabilitation Hospital Eforie Nord, Eforie Nord, Rumania.

${ }^{4}$ Clinical County Hospital of Constanta, Constanta, Rumania.
} 
The assessment of imaging data was made with CT, CT 3D and MRI investigations from the 120 subjects in the study (Fig. 2).

All direct measurements were performed by means of a digital meter, with a $0.01 \mathrm{~mm}$ calibration level and introduced in formulae, while the assessment of CT 3D and MRI images, the dimensional calculation and the angle calculation could be directly achieved with the implemented software (Cramer et al., 1994; Silva et al,. 1994; Zhou et al., 2000; Edmondston et al., 2000).

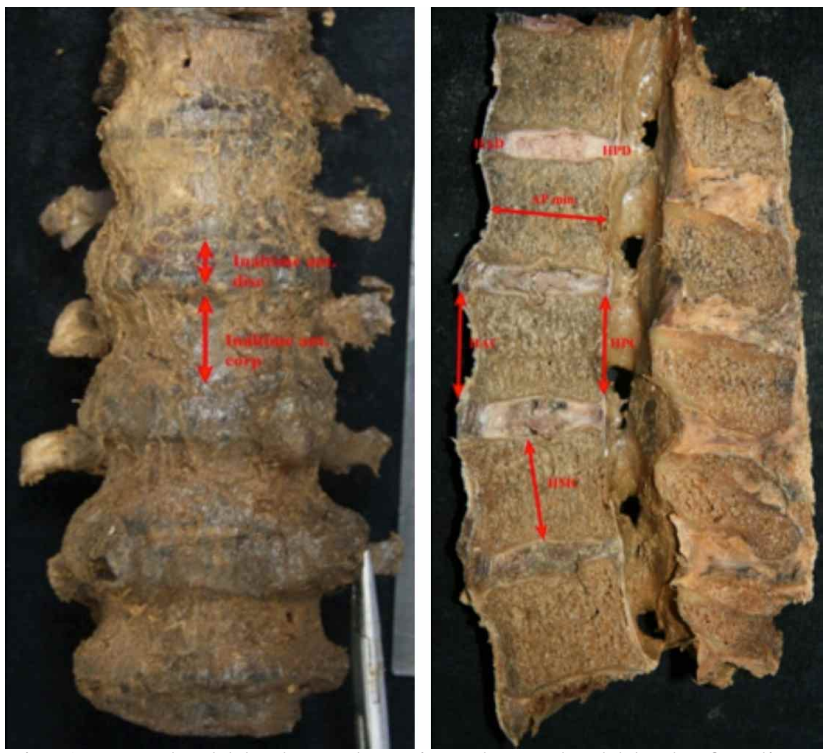

Fig. 1. Vertebral blocks and sectioned vertebral blocks for direct morphometric data (personal archive).
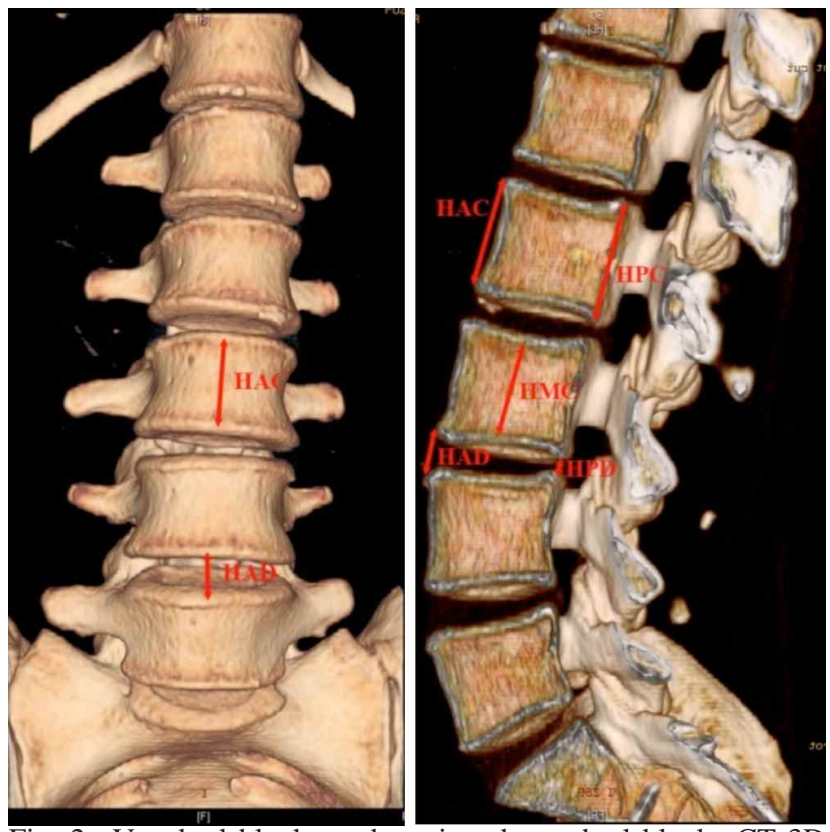

Fig. 2. Vertebral blocks and sectioned vertebral blocks CT 3D reconstructed images (personal archive).

\section{RESULTS AND DISCUSSION}

The disk sizes were assessed by direct measurements (Fig. 3) on the anatomic items and directly measured by means of the software for modern imaging examination.

In case of significant differences between the vertebral bodies, the calculation of disk sizes was made indirectly, on grounds of the geometric interpretation of the vertebral body face sizes (Eijkelkamp, 2002). Thus, we started from marking the extreme contact points between the body and the disk, represented by the most protruding vertebral points in the direction of the intervertebral disk, a, b, c, d, as well as the half distances a-b and c-d, respectively, which distances represent the anterior-posterior maximum diameters of adjacent vertebrae. The height of intervertebral disk is obtained with perpendicular lines drawn through the extreme points to the medial-sagittal line, respectively by adding the halves so obtained (A+ A', M + M', P+ P') (Fig. 4).

Specifically, the imaging assessment allowed the average values of the intervertebral disk height to be recorded according to sex and age groups (Twomey \& Taylor, 1987; Scoles et al., 1988). The average values of the intervertebral disk heights and the evolution of anterior and posterior heights of the lumbar intervertebral disk for the lumbar region obtained by imaging assessment are presented in Figure. terms (Table I, Fig. 5).

Table I. Average heights of intervertebral disks per lumbar levels, obtained by direct measurement

\begin{tabular}{lccc}
\hline & $\begin{array}{c}\text { Anterior } \\
\text { height }\end{array}$ & $\begin{array}{c}\text { Posterior } \\
\text { height }\end{array}$ & Average \\
\hline L1-L2 & 10.71 & 5.1 & 7.91 \\
L2-L3 & 13.16 & 6.14 & 9.65 \\
L3-L4 & 15.55 & 7.05 & 11.30 \\
L4-L5 & 17.81 & 7.68 & 12.75 \\
L5-S1 & 16.92 & 7.14 & 12.03 \\
\hline
\end{tabular}

Both values distributions show a more than significant correlation level, respectively R2 $=0.9754$ and $\mathrm{R} 2=0.9131$, thus demonstrating the statistical certainty of the assessment. Figure 6 show the evolution of intervertebral disk height during three decades of active life, respectively 30-60 years.

We can assess that, at the upper levels of the lumbar segment, the evolution is relatively uniform, while the highest dimensional variations are recorded at the inferior 

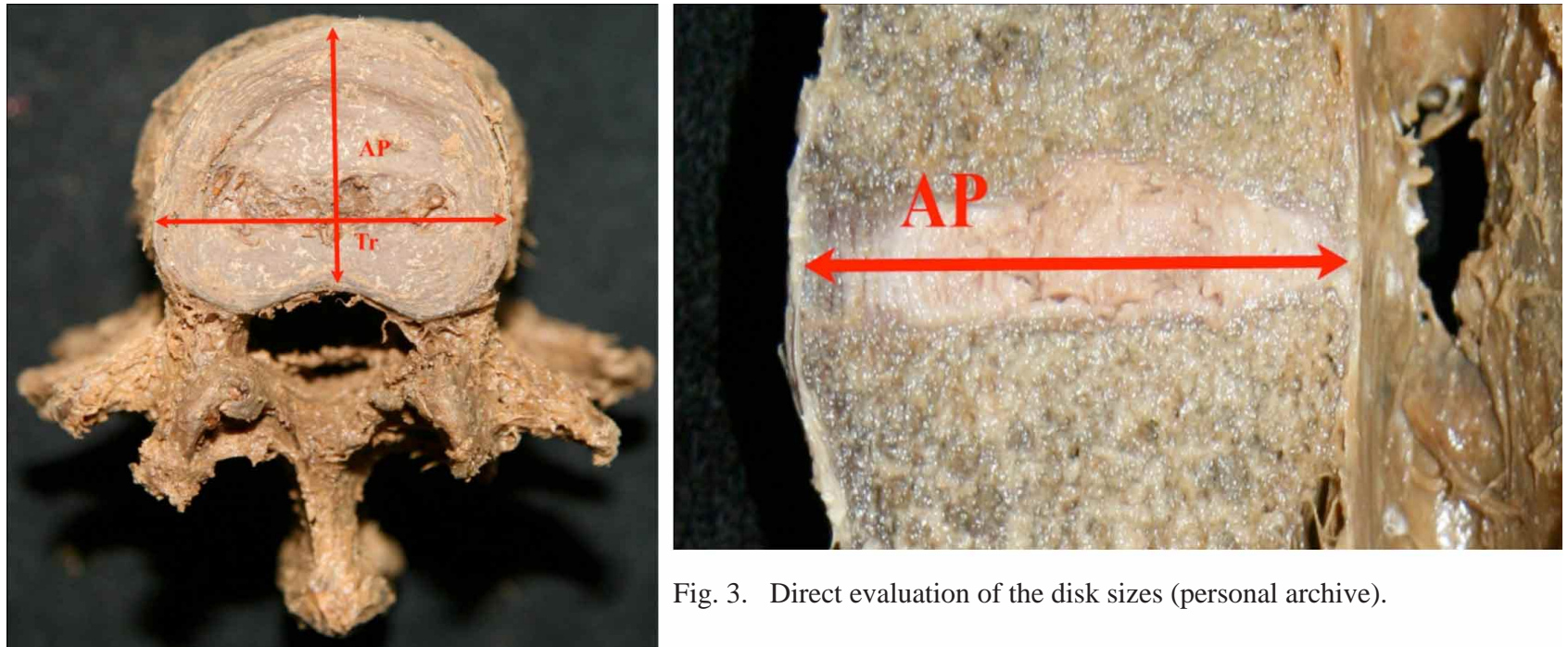

Fig. 3. Direct evaluation of the disk sizes (personal archive).

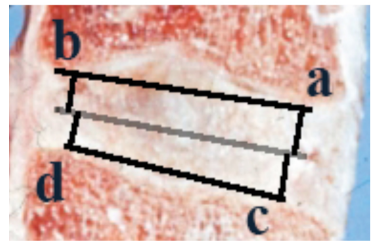

Fig. 4. The pattern for indirect measurement for anterior, medium and posterior height of intervertebral disk (Eijkelkamp)

\section{Evolution of the height of the IV disk}

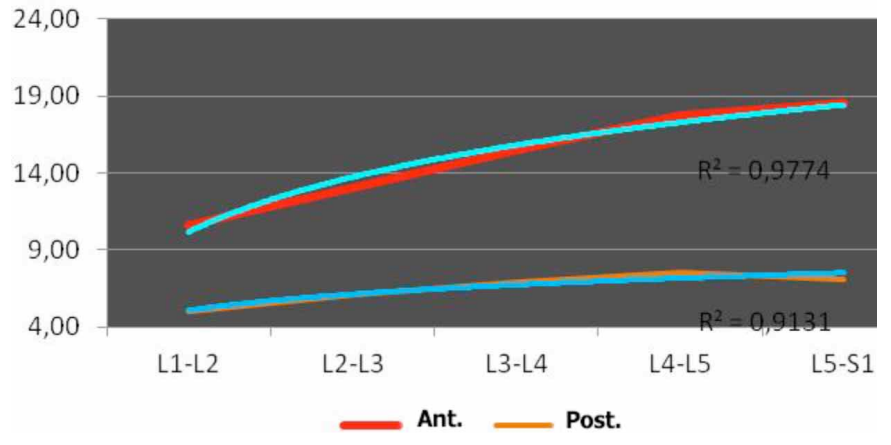

Fig. 5. AHIVD and PHIVD = anterior and posterior heights of intervertebral(IV) disk.

levels, L3 - L4 and L4 - L5. A higher disk at active ages is a biomechanical win, however, for the same disk, at older ages, it will have no advantage, on the contrary it may actually turn into a pathological issue if the IVD structural and composition changes are considered in time.

The most efficient and convenient method to assess and express the angles formed by the adjacent faces of vertebral bodies, respectively the disk angle, is represented by the measurement by means of modern imaging software (Cramer et al.), such as MRI and / or CT 3D, which software, if well calibrated, provides high accuracy data in real time at high speed (Fig. 7).

The IVD height reduction in time is a structural certainty, largely explained by the degenerative changes occurring at this level.

In Table II are represented the differences of absolute values from anatomic and imaging measure, given by the presence of surrounding tissues (soft tissues, ligaments, minor osteophytes, etc.); the low value of the anatomic-imaging variation coefficient, however, confirms the morphometric accuracy level of imaging methods, for which reason imaging is self-sufficient as superior method, especially modern methods allowing fine assessments and calibrations.

For a better representation of the relations between the various structural elements in the region and, especially, to describe the body-disk assembly, the absolute dimensional values can generate useful morphometric indices illustrating more efficiently the specific region aspects, easier to handle and, at the same time, report the existing data in the literature (Table III).

We also calculated two specific indicators for the vertebral body / intervertebral disk assembly, namely: the relative disk-vertebral index and the disk-vertebral angle index. The relative disk-vertebral index (R.I), respectively the disk height-body height ratio (Brandner, 1970; Amonoo-Koufi, 1985, 1991; Aydinlioglu et al., 1999), adds to the disk-vertebral angle degree attempting 


\section{Evolution of the Anterior Height upon age}

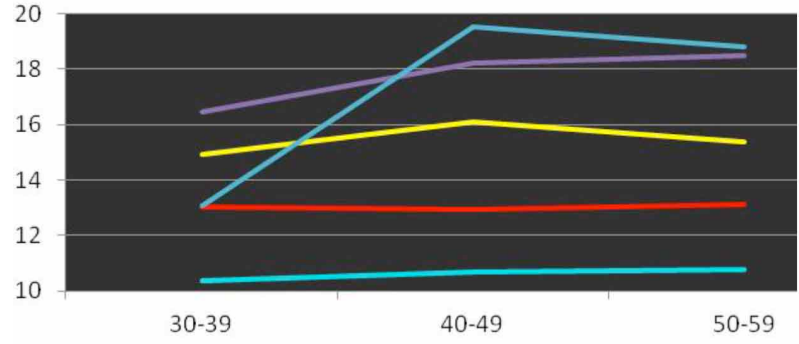

A

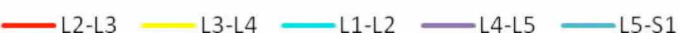

\section{Evolution of the Posterior Height upon age}

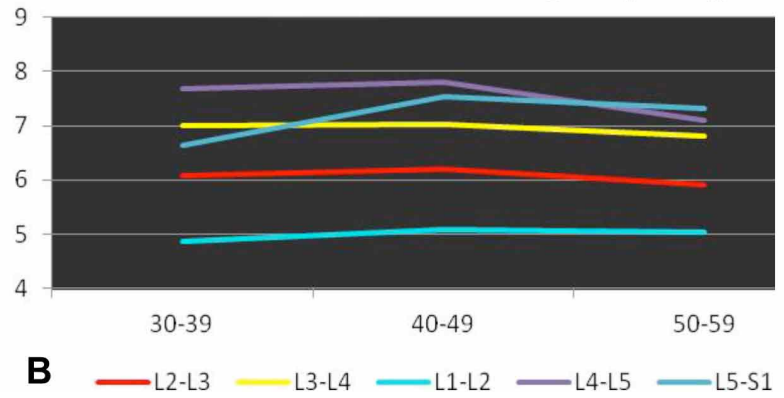

Fig. 6. A and B. Age evolution of anterior and posterior height IVD.
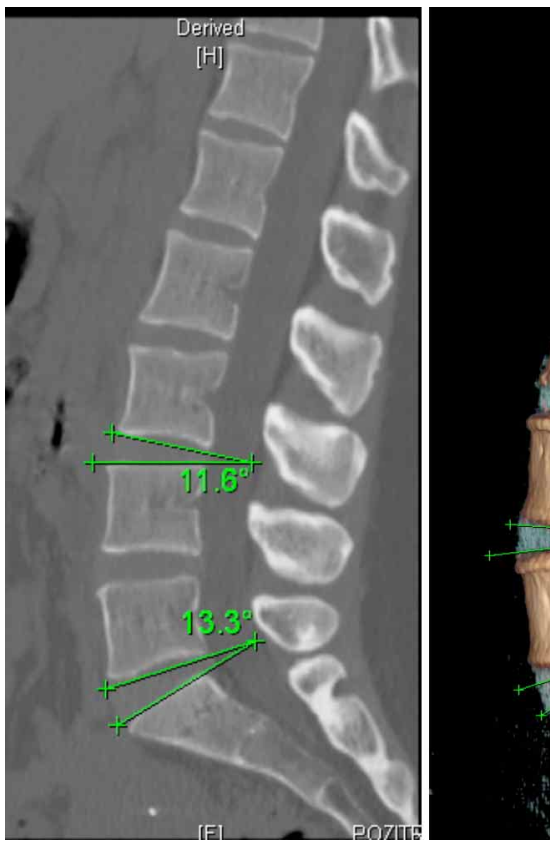

Fig. 7. Wedge (disk) angle- classic CT and CT 3D (personal archive).

the data of other authors (Table IV), between 3.99 and $8.75 \%$, such differences being explained by the fact that both authors used the maximum values of the height of the body and the corresponding disk. This is also confirmed by the similarity with the results provided by Amono-Kuofi for 615 cases applying a similar calculation formula.

We consider that the values we obtained are more reliable in reference to dimensional ratios between the vertebral-disk elements than the ones obtained by the old formula, namely the direct ratio of the intervertebral disk height and the corresponding vertebral body height. An issue to be noted is the one concerning the relative index distribution per age groups (Fig. 8).

Clinical studies (Iliescu et al., 2009, 2012; Niosi et al., 2004; Turk \& Celan, 2004) showed an increase in the idiopathic low back pain incidence at young and active ages (little over 30 years old), when the physical activity can be significant; this

to complete as precisely as possible the image of dimensional ratios between the body and the disk and obtaining the ratio between the sum of intervertebral disk heights (AHIVD and PHIVD) and the sum of corresponding vertebral bodies heights $(\mathrm{AHV}+\mathrm{PHV})$. R.I = AHIVD + PHIVD / AHV + PHV. By its calculation method, the relative disk-vertebral index represents the parameter most faithfully monitoring the changes liable to occur in the functional assembly disk / body, for which reason it is recommended to quantify it in evolution. Another argument in the favor of this assertion is that the change of the relative disk-vertebral index can be induced, especially in degenerative situations, from dimensional variations at the intervertebral disk level (more frequently) and at the level of the vertebral body (seldom, but not impossible). As compared to some data in the literature, the values obtained by the study are lower than age involves multiple factors which can derive from a relatively lower height of the intervertebral disk, as well as congruence issues of joint apophyses, posterior longitudinal ligament relaxation, etc. The increase of the relative index in decades 5 and 6, obviously due to the IVD height increase can add to the correction of such deficits, the hypothesis, further being supported by the clinical studies confirming some improvement of the symptoms in time.

Disk-vertebral angle index (wedge index-WI). The dimensional values of the vertebral body and intervertebral disk can be globally and highly suggestively expressed by the disk angle (wedge index) and must not be mistaken for the vertebral-disk angle (Aharinejad et al.; Eijkelkamp; Aydinlioglu et al.; Amono-Kuofi; Gepstein et al., 1991). There are two methods to calculate this index: 


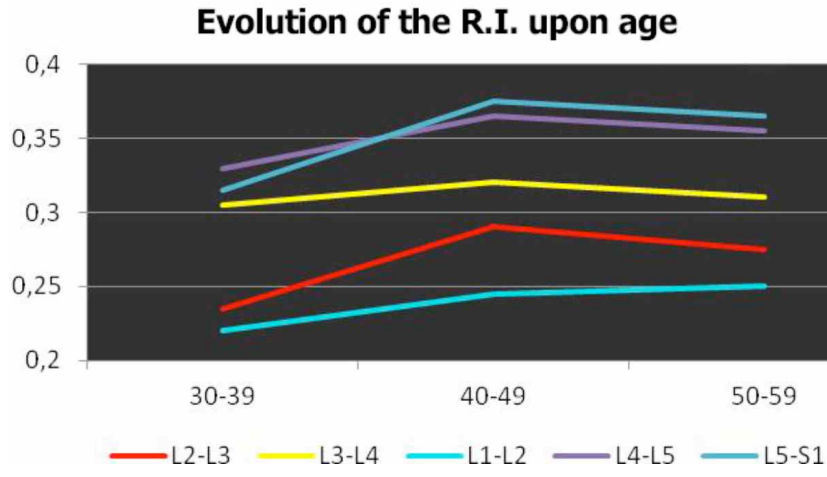

Fig. 8. The relative index distribution per age groups.

Table II. Absolute values and anatomic-imaging variation coefficients for the vertebral-disk angle

\begin{tabular}{cccc}
\hline Level & Direct & Imagistic & $\begin{array}{c}\text { Variation } \\
\text { coefficient }\end{array}$ \\
\hline L1-L2 & 5.8 & 5.2 & 1.12 \\
L2-L3 & 6.2 & 5.9 & 1.05 \\
L3-L4 & 7.1 & 76.8 & 0.09 \\
L4-L5 & 10.2 & 9.7 & 1.05 \\
L5-S1 & 13.4 & 12.8 & 1.05 \\
\hline
\end{tabular}

- calculation according to the formula AHIVD - PHIVD / APD, where APD represents the maximum anterior-posterior disk diameter (AHIVD and PHIVD are the anterior, respectively posterior height of the disk);

- calculation according to the formula sin-1 x (AHIVD PHIVD) / 1/2 (SD + ID), where SD and ID are the superior, respectively inferior diameters of the vertebral faces adjacent to the disk.

It is interesting the manner in which this "wedge index" evolves per age groups, for each lumbar level (Fig. 9).

A brief analysis of the value distribution per age groups will show that, similarly to the other indices, the diskvertebral angle index also, for the inferior level L3 -L5 is the one recording the most significant changes. Also, starting with the 5th decade, the trend of this index is to stabilize, the trend being explained by the structural changes occurring in the body-disk assembly (Twomey \& Taylor; Scoles et al.). The vertebral-disk angle index has special effects, both in physiological and pathological terms. The vertebral-disk angle is the one imprinting the lumbar spine lordosis level; in case of normal lordosis, the angle of vertebral bodies contributes with approximately 300 , and the disk angle with 60. As compared to some literature data, the average value of disk-vertebral angle indices shows as follows (Table V and Fig. 10).

Table III. Average heights of intervertebral disks per lumbar levels, compared to literature.

\begin{tabular}{lccccc}
\hline Level & Personal cases & $\begin{array}{c}\text { Campbell et al. } \\
2005 \\
\text { (39 cases) }\end{array}$ & $\begin{array}{c}\text { Busscher etal. } \\
2001 \\
\text { (6 cases) }\end{array}$ & $\begin{array}{c}\text { Aydinlioglu } \\
\text { et al. } 1999 \\
\text { (200 cases) }\end{array}$ & $\begin{array}{c}\text { Eijkelkamp } \\
\text { (73 cases) }\end{array}$ \\
\hline L1-L2 & 7.91 & 8.4 & 10.3 & 8.2 & 10.2 \\
L2-L3 & 9.65 & 9.3 & 11.5 & 10.1 & 12.1 \\
L3-L4 & 11.30 & 10.1 & 11.8 & 12.1 & 12.5 \\
L4-L5 & 12.75 & 10.5 & 12.7 & 13.1 & 13.7 \\
L5-S1 & 12.03 & 9.4 & 8.8 & 11.9 & 13.2 \\
\hline
\end{tabular}

Table IV. Comparative relative disk-vertebral index (RI) (imaging exploration).

\begin{tabular}{ccccc}
\hline Level & $\begin{array}{c}\text { Personal } \\
\text { cases }\end{array}$ & $\begin{array}{c}\text { Brandner } \\
(187 \text { cases })\end{array}$ & $\begin{array}{c}\text { Aydinlioglu } \\
(200 \text { cases })\end{array}$ & $\begin{array}{c}\text { Amono-Kuofi } \\
(615 \text { cases })\end{array}$ \\
\hline $\mathbf{L}_{\mathbf{1}}-\mathbf{L}_{\mathbf{2}}$ & 0.235 & 0.252 & 0.25 & 0.229 \\
& & $(6.75 \%)$ & $(6 \%)$ & $(-1.29 \%)$ \\
$\mathbf{L}_{\mathbf{2}}-\mathbf{L}_{\mathbf{3}}$ & 0.2667 & 0.286 & 0.2917 & 0.258 \\
& & $(6.76 \%)$ & $(8.75 \%)$ & $(-2.18 \%)$ \\
$\mathbf{L}_{\mathbf{3}}-\mathbf{L}_{\mathbf{4}}$ & 0.3117 & 0.334 & 0.3383 & 0.319 \\
& & $(6.69 \%)$ & $(7.88 \%)$ & $(2.29 \%)$ \\
$\mathbf{L}_{\mathbf{4}}-\mathbf{L}_{\mathbf{5}}$ & 0.3533 & 0.368 & 0.375 & 0.349 \\
& & $(3.99 \%)$ & $(5.78 \%)$ & $(-1.23 \%)$ \\
$\mathbf{L}_{\mathbf{5}}-\mathbf{S}_{\mathbf{1}}$ & 0.3585 & 0.379 & 0.3783 & 0.357 \\
& & $(5.45 \%)$ & $(5.29 \%)$ & $(-0.42 \%)$ \\
\hline
\end{tabular}


Evolution of the W.I. upon age

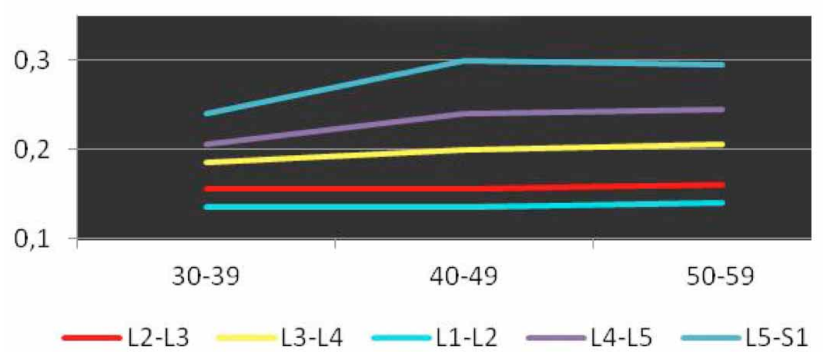

Fig. 9. The wedge index distribution per age groups.

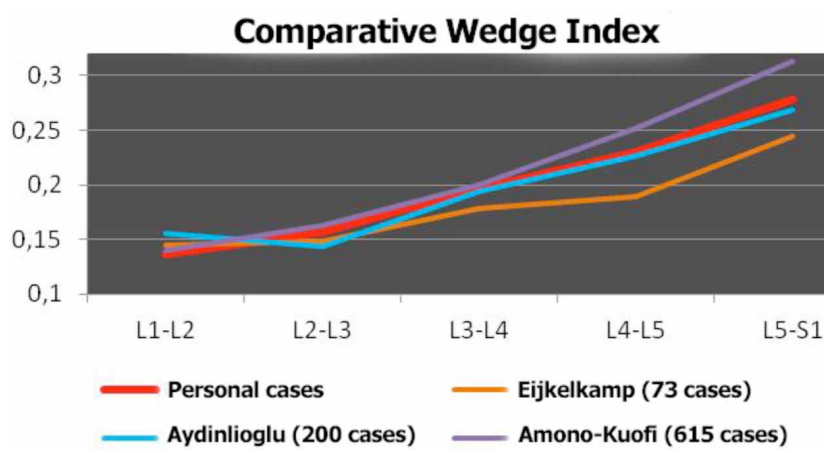

Fig. 10. Disk-vertebral angle index (wedge index), compared to literature.

Both statistically and dynamically, the intervertebral disk is subject to massive stress, not only due to the body weight itself, but also due to the muscle stress, compressive and tensioning, as well as the shearing forces induced by the same muscular jacket (Iliescu, 2011). In such conditions, the disk-vertebra angle becomes a prevention factor for disk protrusion towards the posterior, while a reduction of this index (and, globally, of the lordosis level) becomes a factor entailing disk protrusion, the aspect being confirmed by the literature also.

\section{CONCLUSIONS}

The vertebral body / intervertebral disk assembly represents a dynamic structure, permanently subject to changes and adaptation, IVD being capable of incurring changes for the entire life time, including growth changes; the growth, however, is not lineal, but a succession of thickening and getting thinner, in full concordance with the structural stresses and changes occurring inside. Moreover, the intervertebral disk shows cyclic periods of volume changes, directly reflected in the response to stresses. After the 5th decade of life, such changes are lower, directly affecting the adaptation capacity of the intervertebral disk, also. Today we are certain that the disk resistance varies differently according to the level of degeneration, namely we see a reduction in the resistance in the case of moderate degeneration and an increase in stiffness, respectively a reduction of the force absorption power in the case of severe degeneration (Niosi et al.; Turk \& Celan; Iliescu). The parallelism between the load stress, on one hand, and the disk degeneration, on the other hand, can entail the fibrous ring in a vicious circle invariably resulting in irreversible ruptures at this level.

ILIESCU, D. M.; BORDEI, P.; IONESCU, E. V.; ALBINA, S.; OPREA, C.; OBADA, B.; LUPU, A. A.; HANGAN, T. L. \& ILIESCU, M. G. Correlaciones anatomopatológicas de los índices morfométricos disco-vertebral lumbar. Int. J. Morphol., 35(4):1553-1559, 2017.

RESUMEN: El estudio representa una evaluación morfométrica del segmento anterior de la columna lumbar, centrado en el conjunto del cuerpo vertebral - disco intervertebral, calculando algunos indicadores específicos y completando los datos morfométricos directos. El objetivo del trabajo fue mapear un modelo de imagen anatómica con los datos de la interpretación de la imagen, posteriormente correlacionando los datos. El estudio se llevó a cabo con artículos anatómicos de archivos personales y de las imágenes obtenidas de tomografía computarizada (TC) y resonancia magnética (RM) de evaluación. La evaluación

Table V. Disk-vertebral angle index (wedge index), compared to literature.

\begin{tabular}{lcccc}
\hline Level & $\begin{array}{c}\text { Personal } \\
\text { cases }\end{array}$ & $\begin{array}{c}\text { Eijkelkamp } \\
(73 \text { cases })\end{array}$ & $\begin{array}{c}\text { Aydinlioglu } \\
(200 \text { cases })\end{array}$ & $\begin{array}{c}\text { Amono-Kuofi } \\
(615 \text { cases })\end{array}$ \\
\hline $\mathbf{L}_{\mathbf{1}}-\mathbf{L}_{\mathbf{2}}$ & 0,1367 & 0,145 & 0,156 & 0,1400 \\
$\mathbf{L}_{\mathbf{2}}-\mathbf{L}_{\mathbf{3}}$ & 0,1567 & 0,148 & 0,0144 & 0,1633 \\
$\mathbf{L}_{\mathbf{3}}-\mathbf{L}_{\mathbf{4}}$ & 0,1967 & 0,178 & 0,194 & 0,2000 \\
$\mathbf{L}_{\mathbf{4}}-\mathbf{L}_{\mathbf{5}}$ & 0,23 & 0,189 & 0,227 & 0,2517 \\
$\mathbf{L}_{\mathbf{5}}-\mathbf{S}_{\mathbf{1}}$ & 0,2783 & 0,245 & 0,268 & 0,3133 \\
\hline
\end{tabular}


morfométrica se realizó en los discos intervertebrales, la altura del disco en las secciones anterior y posterior y se correlacionó con el grado del ángulo del disco. Se compararon los datos morfométricos directos y se correlacionaron con los datos resultantes de la interpretación de la imagen. Se realizó una evaluación morfométrica directa de 11 bloques vertebrales; Los bloques vertebrales se seccionaron y se convirtieron en 22 semibloques vertebrales permitiendo el fácil acceso a todos los valores dimensionales, incluyendo aquellos cubiertos por el arco posterior. La evaluación de los datos de imagen se realizó en 120 sujetos con CT, CT 3D y MRI. Los tamaños de los discos se evaluaron mediante medidas directas de los elementos anatómicos y se midieron con el software para la examinación de imágenes. En caso de diferencias significativas entre los cuerpos vertebrales, el cálculo de los tamaños de los discos se realizó indirectamente, debido a la interpretación geométrica de los tamaños de la cara del cuerpo vertebral. El conjunto cuerpo vertebral / disco intervertebral (CVDV) representa una estructura dinámica, permanentemente sujeta a transformaciones y adaptación, siendo (CVDV) capaz de incurrir en cambios durante toda la vida, incluyendo aquellos relacionados con crecimiento. El crecimiento, sin embargo, no es lineal, sino una sucesión de engrosamiento y adelgazamiento, en plena concordancia con las tensiones estructurales y los cambios que se producen en su interior.

PALABRAS CLAVE: Espina lumbar; Morfometría directa; Bloques vertebrales.

\section{REFERENCES}

Aharinejad, S.; Bertagnoli, R.; Wicke, K.; Firbas, W. \& Schneider, B. Morphometric analysis of vertebrae and intervertebral discs as a basis of disc replacement. Am. J. Anat., 189(1):69-76, 1990.

Amonoo-Koufi, H. S. The sagittal diameter of the lumbar vertebral canal in normal adult Nigerians. J. Anat., 140(Pt. 1):69-78, 1985.

Amonoo-Kuofi, H. S. Morphometric changes in the heights and anteroposterior diameters of the lumbar intervertebral discs with age. J. Anat., 175:159-68, 1991.

Aydinlioglu, A.; Diyarbakirli, S. \& Kele_, P. Heights of the lumbar intervertebral discs related to age in Turkish individuals. Tohoku J. Exp. Med., 188(1):11-22, 1999.

Brandner, M. E. Normal values of the vertebral body and intervertebral disk index during growth. Am. J. Roentgenol Radium Ther. Nucl. Med., 110(3):618-27, 1970.

Busscher, I.; Ploegmakers, J. J.; Verkerke, G. J. \& Veldhuizen, A. G. Comparative anatomical dimensions of the complete human and porcine spine. Eur. Spine J., 19(7):1104-14, 2010.

Campbell-Kyureghyan, N.; Jorgensen, M.; Burr, D. \& Marras, W. The prediction of lumbar spine geometry: method development and validation. Clin. Biomech. (Bristol, Avon), 20(5):455-6, 2005.

Cramer, G. D.; Howe, J.; Glenn, W. V.; Greenstein, J. \& Potvin, W. Morphometric comparison of computed tomography to magnetic resonance imaging in the evaluation of the lumbar intervertebral foramina. Clin. Anat., 7(4):173-80, 1994.

Edmondston, S. J.; Song, S.; Bricknell, R. V.; Davies, P. A.; Fersum, K.; Humphries, P.; Wickenden, D. \& Singer, K. P. MRI evaluation of lumbar spine flexion and extension in asymptomatic individuals. Man. Ther, 5(3):158-64, 2000.

Eijkelkamp, M. F. On the Development of an Artificial Intervertebral Disc. $\mathrm{PhD}$ Thesis. Groningen, University of Groningen, 2002.
Gepstein, R.; Folman, Y.; Sagiv, P.; Ben David, Y. \& Hallel, T. Does the anteroposterior diameter of the bony spinal canal reflect its size? An anatomical study. Surg. Radiol. Anat., 13(4):289-91, 1991.

Iliescu, D.; Apte, E. \& Iliescu, M. Morphometric particularities of bone elements from cervical region. Rom. J. Funct. Clin. Anat. Anthropol., 2:24-30, 2006

Iliescu, M. G. Anatomical-Clinical-Imagistical Considerations in Mechanical Low Back Pain. Ph.D. Thesis. Constanta, Ovidius University of Constanta, 2011.

Iliescu, M.; Bordei, P.; Iliescu, D.; Ciobotaru, C.; Lucescu, V.; Covaleov, A. \& Ionescu, C. Anatomo-clinical and imagistic correlations within the lumbar discopathy. Surg. Radiol. Anat., 31(1 Suppl.):145-6, 2009.

lliescu, M.; Bordei, P.; Albina Sandica \& Ionescu, C. Morphology of the intervertebral foramen: a direct relation with low back pain. ARS Med. Tomitana, 18(2):62-65, 2012.

Niosi, C. A. \& Oxland, T. R. Degenerative mechanics of the lumbar spine. Spine J., 4(6 Suppl.):S202-8, 2004.

Nissan, M. \& Gilad, I. Dimensions of human lumbar vertebrae in the sagittal plane. J. Biomech, 19(9):753-8, 1986.

Panjabi, M. M.; Goel, V.; Oxland, T.; Takata, K.; Duranceau, J.; Krag, M. \& Price, M. Human lumbar vertebrae. Quantitative three-dimensional anatomy. Spine (Phila Pa 1976), 17(3):299-306, 1992.

Scoles, P. V.; Linton, A. E.; Latimer, B.; Levy, M. E. \& Digiovanni, B. Vertebral body and posterior element morphology: the normal spine in middle life. Spine (Phila Pa 1976), 13(10):1082-6, 1988.

Silva, M. J.; Wang, C.; Keaveny, T. M. \& Hayes, W. C. Direct and computed tomography thickness measurements of the human, lumbar vertebral shell and endplate. Bone, 15(4):409-14, 1994.

Turk, Z. \& Celan, D. Importance of intervertebral disc size in low back pain. Croat. Med. J., 45(6):734-9, 2004.

Twomey, L. T. \& Taylor, J. R. Age changes in lumbar vertebrae and intervertebral discs. Clin. Orthop. Relat. Res., (224):97-104, 1987.

van der Houwen, E. B.; Baron, P.; Veldhuizen, A. G.; Burgerhof, J. G.; van Ooijen, P. M. \& Verkerke, G. J. Geometry of the intervertebral volume and vertebral endplates of the human spine. Ann. Biomed. Eng., 38(1):33-40, 2010.

Zhou, S. H.; McCarthy, I. D.; McGregor, A. H.; Coombs, R. R. \& Hughes, S. P. Geometrical dimensions of the lower lumbar vertebrae--analysis of data from digitised CT images. Eur. Spine J., 9(3):242-8, 2000.

\section{Corresponding author: \\ Madalina-Gabriela Iliescu \\ Assistant Professor \\ 1 Universitatii Alley \\ Campus - Corp B \\ 900470 Constanta \\ ROMANIA}

E-mail: iliescumadalina@gmail.com

Received:02-06-2017

Accepted:14-07-2017 